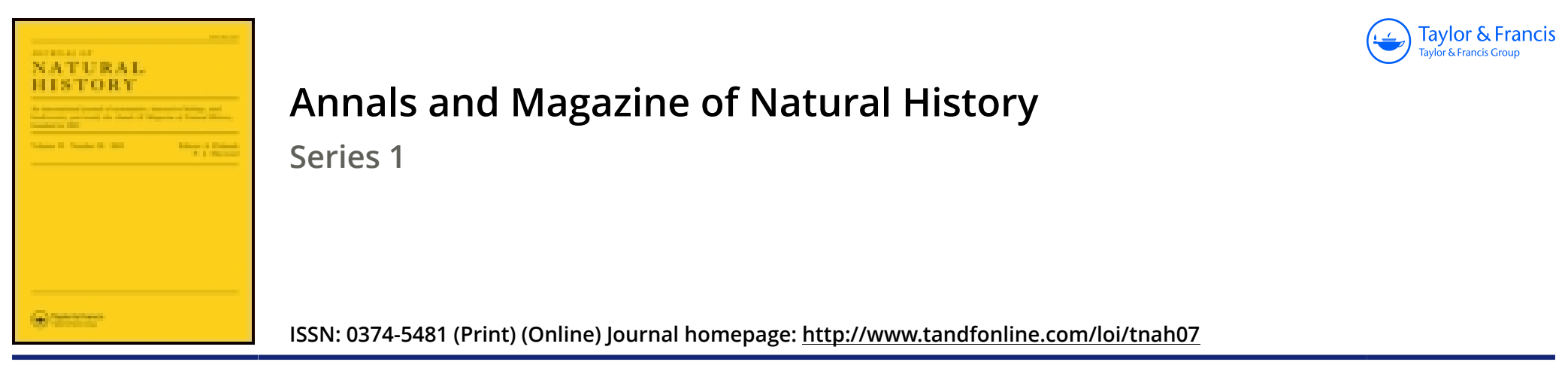

\title{
Habits of snails or black slugs (Arion ater.)
}

\author{
J. E. Gray
}

To cite this article: J. E. Gray (1838) Habits of snails or black slugs (Arion ater.), Annals and Magazine of Natural History, 2:10, 310-310, DOI: 10.1080/00222933809496683

To link to this article: http://dx.doi.org/10.1080/00222933809496683

册 Published online: 15 Mar 2010.

Submit your article to this journal 중

III Article views: 3

Q View related articles $\asymp$ 
nABITS OF SNAILS OR BLACK SLUGS (ARION ATER.).

Several instances have been adduced of the land Helices eating meat and other extraordinary substances, and I have often observed the garden snails (Helix aspersa) eating the paper of the posting bills from the walls of the environs of London after a shower, but I was not aware until the other day, when I was near Newcastle, that they would eat inorganic matter. But having met with a black slug, (Arion ater,) and for safety'placed it in a box with some sea-sand, just taken from the sea for the purpose of examining the fragments of animal matter which renders it luminous when trodden on in the dark, I was surprised on opening it to observe that the slug had been eating the sand, until its freces, which were first of a green vegetable colour, were entirely composed of pure sand, united together into their usual form by a little mucus. When first the slug was placed in the box, the irritation of the salt caused it to emit a quantity of mucus, but it very shortly became reconciled to its abode, and lived in it for several days, though the box was open; but at length escaped.-J. E. Gray.

REGULUS MODESTUS, GOULD, A BRITISA BIRD.

I beg to hand you a notice of a very scarce and interesting species of Regulus, which I shot on the banks near Hartley, on the coast of Northumberland, on the 26th of last September ; it corresponds exactly with Gould's Regulus modestus, a species so extremely rare, that he considers the individual from which he described as unique in the continental collections. The description of my bird, which will now entitle this species to a place in the British Fauna, is as follows:

Length, $4 \frac{1}{16}$ in.; breadth, $6 \frac{1}{2}$ in.; length from the carpus to the end of the wing, $2 \frac{1}{16}$ in.; tail, $1 \frac{1}{16}$ in.; the bill from the gape to the tip nearly $\frac{7}{16}$ in., and from the tips of the feathers, which extend to the extremity of the nostrils, $\frac{1}{4}$ in.

The whole of the upper plumage a greenish yellow; on the centre of the crown of the head is a streak of paler; a light lemon-coloured streak extends over the eye from the base of the bill to the occiput; a short streak of the same colour passes beneath the eye, and a narrow band of dusky passes through the eye and reaches the termination of the auriculars. 'The under parts pale yellow; the ridge of the wing bright lemon colour; wing feathers dusky, edged with pale yellow, becoming broader on the secondaries; two conspicuous bands of lemcn colour cross the coverts; the wings reach to within $\frac{3}{4}$ in. of 